\title{
Introducing Ecolinguistics in EFL Classroom
}

\author{
$1^{\text {st }}$ Maria Arina Luardini \\ Faculty of Education and Teacher Training \\ University of Palangka Raya \\ Palangka raya, Indonesia \\ maria_luardini@edu.upr.ac.id
}

\author{
$2^{\text {nd }}$ Erma Sujiyani \\ Faculty of Education and Teacher Training \\ University of Palangka Raya \\ Palangka raya, Indonesia \\ esyani@gmail.com
}

\begin{abstract}
Referring to the new policy on National Curriculum of 2013, in which one of its objectives is to empower teachers to develop the potential of the region, and answering the gap between the curriculum demand on the local content development and the lack of local content development on the provided materials being used to teach English in Central Kalimantan, this paper attempts to introduce ecolinguistics as the local content development in EFL classrooms of Junior High School level. The ecolinguistics inserted in the lesson plan is a narrative text of a local story, and a procedure text of how to make traditional soup from young rattan. The teaching model was executed in SMPN 1 and SMPN 3, Kuala Kapuas. The teaching English using ecolinguistics was completed with exercises for students to comprehend meanings of a lexicon list of environmental expressions taken from the texts and use them in their writing. Understanding ecolinguistics the use of environmental linguistic expressions will lead to a meaningful teaching and learning process. Therefore, as the follow-up it is necessary to develop instructional material consisting of environmental linguistic expressions.
\end{abstract}

Keywords: curriculum, ecolinguistics, local content, ecolinguistic-based lesson plan.

\section{INTRODUCTION}

Curriculum as stated on National Education System on Act Number 20 Year 2003 means a set of plans and regulations about the aims, contents and material of lessons and the methods employed as the guidelines for the implementation of learning activities to achieve given education objectives. It is used as the base of any learning institution to provide students with a set of instructional activities consisting of several important elements specifically learning objectives, the units and lessons should be learned by the students, teaching procedures, the books and materials used by the teachers, and tool of assessment. In Indonesia, there have been several changes on the implementation of curriculum; currently the new curriculum implemented is the Curriculum 2013 or K13. Different from the previously implemented curriculum, as stated by Nur and Madkur (2014), this new curriculum contains innovations to create better learning practice, which is intended mainly to improve the quality of the students. According to Dharma (2008), it should be basically developed based on diversified principles related to educational unit, regional potential, and the learners, as well as include local content as one of its education objectives.

In relation with the realization of curriculum in classroom, teachers as the key factor of curriculum executor, play a crucial role. Teachers should be able to implement the curriculum through various ways involving the employment of multi-strategy, multimedia approach, sufficient learning and technology sources, and by utilizing immediate environment as learning source (Dharma, 2008). However, in reality particularly in Central Kalimantan, the implementation of K-13 by teachers in accordance with English as the learning subject has discrepancy with the objectives requested by the curriculum. According to the National Curriculum of 2013 and the Governor Regulation of Central Kalimantan or Pergub Kalimantan Tengah Number 22 Year 2011, English teachers are required to develop the potential of the region to be incorporated with the teaching learning activities, whereas the provided materials being used to teach English do not have local content development. Therefore, this paper attempts to answer the demand of the curriculum by introducing ecolinguistics as the local content development in EFL classroom of Junior High school level. For that reason the discussion of this paper begins with ecolinguistics, followed by ecolinguistics in EFL classroom, the advantages of ecolinguistics in EFL classroom, and the development of ecolinguistic-based lesson plan.

\section{ECOLINGUISTICS}

The Norwegian linguist, Einar Haugen (1972), initiated the study of ecolinguistics by using the term of language ecology through a metaphor study by adapting interrelationship of living being as organisms and their environment. The organism is metaphorically considered as a language and the environment of language is the social practices within social life (culture, education, politics, or beliefs). This biological analogy develops into some perceptions that language has its family in which it interbreeds, varies, and can be maintained; otherwise it would be the language's death. He considered language ecology as an approach to linguistics and defined it as "a study of interactions between any given language and its environment" (Haugen, 1972, p. 323). 
After Haugen's language ecology, some linguists develop theories of language based on principle of ecology. Therefore, the role of ecolinguistics nowadays is getting wider expanding into many scopes, but the more relevant one with this paper concerns with biological, physical and social environment context. Or in another word, the ecolinguistics referred in this paper is similar to the ecolinguistics defined as "the ecological approach to language takes into consideration the complex network of relations occurring between environment, languages and people speaking these languages" (Wendel, 2005, p. 51). The environment in this context means the natural, social and cultural surroundings of the people who speak the languages, and the languages in this context can be the language(s) people use and speak for daily communication or the language they learn and study in formal or informal places, such as at schools. In this case, there is interrelation and diversity among different languages, the people who use the languages, and the natural, social and cultural setting where the people live. This interrelation and diversity includes the environment of education for teaching language. Accordingly in line with this paper, ecolinguistics is used as an approach to teach English as a foreign language in Indonesia. Through this approach, English is taught to the students by relating between the lesson in the classroom and the students' real life. This matter is explained further in the following discussion.

\section{ECOLINGUISTICS IN EFL CLASSROOM}

English has become the first foreign language to be learnt as a compulsory subject at junior and senior high school levels in Indonesia and is considered as a permanent course in the curriculum. As a foreign language subject, English is taught to make the students be able to know and distinguish the correct and incorrect, appropriate and inappropriate ways of using the language. It is also learnt mainly in classrooms and it is not used as a daily means of communication among people outside of the classroom.There are two significant factors determining the success of teaching learning English as a foreign language. The first factor is the role of the teacher. English teachers have essential role to give input and exposure on the language use in the classroom. English teachers are expected to be able to teach English effectively and create the teaching learning process in the classroom as interactive and meaningful as possible. In addition, as requested in the curriculum, English teachers should be able to develop the potential of the region as local content to be incorporated with the teaching learning activities. Local content discussed in this paper is the natural, social and cultural environment, as well as the needs of the region that must be studied by students in a certain area.
Another factor determining success in teaching learning English in the classroom is the learning materials provided in the class. As students' exposure to English is limited, the materials given to students should boost their motivation in learning English and engaged them to the class atmosphere and learning activities. However, the materials being used in EFL teaching and learning hardly ever involve the natural and cultural setting where the language learners live and have daily interaction each other. Students are often provided with the context of having no close relation to their everyday life. The context used as found in the provided materials for teaching English mostly is based on inauthentic context having more formal and well-structured pattern of standardized English supported by texts, dialogues, and other aspects of global content. This makes the students feel less-connected with the learning materials and results in certain difficulties for practicing their English language skills. Moreover, most teachers also tend to fulfill their teaching responsibility by using the provided materials assigned in the curriculum to prepare students for the national examination. Consequently, students are not well-guided for gaining practice in using and implementing the language skills competencies in the classroom.

Realizing the aforementioned matter, to make students more connected to learning materials used in the classroom and to make teachers fulfill the curriculum demand on the local content development, ecolinguistics can be taken into account as one alternative of solution. Ecolinguistics can be used as an approach to teach English as a foreign language. As stated previously, ecolinguistics links the study of language with ecology or environment, so by using ecolinguistics approach, students learn English to represent the nature or environment of where they deal with everyday. To enhance and give exposure on the language skills competencies, students are trained by using learning materials that link them to their everyday surroundings naturally and culturally. When students know the relationships between the lesson in the classroom and real life, they realize the advantages or significances of learning.

To implement ecolinguistics in EFL classroom, teachers' creativity in designing teaching materials or learning experience and assignment for conducting meaningful learning involving students' real life situation in classroom routines is needed. The material should be in accordance with the syllabus of junior high school level. Indeed that the curriculum used by junior high schools are varied: some still use the old version known as School-Based Curriculum (KTSP), and the other applied the new curriculum of Curriculum 2013 (K-13). However, contents of the two curricula adopt Genre-Based Approach in which they focus on language use of transactional and functional texts from very simple short texts up to functional long texts. The contents are divided into 
four language skills: listening, reading, speaking, and writing. For grade VII which is the lowest level to study foreign language of English consists of simple texts, such as greetings, introducing others, describing people, place, and thing. This paper is then focused on the material for the graders of VIII as the texts are developed into longer texts, although some are still in short texts. Therefore, the focus of language teaching is more on the productive skills (speaking and writing). However, it is still possible for the teachers to use the materials for perceptive skills (listening and reading).

The implementation of ecolinguistics for the meaningful EFL teaching and learning in the classroom can be combined with several approaches such as Behaviorism, Contextual Teaching and Learning (CTL), or Scientific Approaches (SA). Behaviorism was first introduced by B.F Skinner in 1904 - 1990 (Morris et. al., 2005) with the psychological principle that has become the fundamental theory of social science. It is considered that learning as a behavior will affect the learner's achievement, especially for learning a language where the learners can be trained by providing a stimulus as their behavior to recognize the responses. Similarly, CTL - an approach in teaching and learning - can help teachers to relate lesson content and the situation of the real world. Basically, the approach of CTL is considered as a response toward previous well-known approaches, behaviorism which stresses stimuli - responds with a drill practice. To be able to use language naturally like the use of language in daily life with various situations, one needs critical thinking and meaningful learning. When students know the relationships between the lesson in the classroom and real life, they realize the advantages/significances of learning. This opinion is in line with SA concept which considers natural situation as the approach. Contextual learning provides a concept which relates the lesson material and the context where that lesson material is used. Context provides meanings, relevance and benefit toward learning.

\section{THE ADVANTAGES OF ECOLINGUISTICS IN EFL CLASSROOM}

There are at least two advantages of implementing ecolinguistics in EFL classroom. The first one is seen from language point of view and the other one is from ecology point of view. From language point of view, the implementation of ecolinguistics in EFL classroom makes students easier in understanding the concepts realized in the learning materials, because it is based on their natural, social and cultural surroundings. They can be actively engaged in the learning activities and they are more motivated in learning English because they can enjoy the classroom atmosphere and feel more connected to the materials being discussed in the classroom. The use of ecolinguistics also involves the local language the students use in their everyday life, by doing so; this will maintain and preserve the existence of local language, the culture and local literature in students' surroundings.

This advantage is supported by the results of researches done by Kana'iaupuni et.al. (2010), Luardini and Simbolon (2016), Singh and EspinozaHerold (2017), and Tjendani (2017). Kana'iaupuni et.al. (2010) conducted a research within Hawaiian culture environment and the results show that culturebased education has closely relationships to the students' socio-emotional well-being which shape their math and reading test scores. Within the Hawaiian culture relationship the students have strong community ties that make them confidently promote their own cultures. Singh and EspinozaHerold (2017) conducted a research on ecolinguistics in the advantages of culture-based education for indigenous students in US and Southeast Asia in a diverse situation that has the positive correlation to students' outcomes, especially in socio-emotional well-being, civic engagement and school motivation. Similarly, a research in teaching English by using ecolinguistics - the use of environmental lexical expressions - conducted for junior high schools (Luardini and Simbolon, 2016) has increased students motivation when they mentioned some familiar lexical expressions, such as rattan, coconut, or the traditional spices. Tjendani (2017) mentioned three advantages of the English learning activities in the classroom based on the ecological linguistics approach focusing on the need for communicative competences related to communication in intracultural contexts, inter-cultural context and transcultural context. The advantages are: 1) learners get easier to comprehend the materials, because it is based on their cultural context of biology, sociology and ideology; 2) learners speeds learning and their learning strategy varies which controlled by how they produce their own communicative competence based on their productive English skills, both of oral and written in a group or individual activities; 3) learners produce English as a tool for making communication than as a language in the form of doing exercises on the papers test.

The second advantage is seen from ecology point of view. As we know that human beings and nature are inseparable, so by implementing ecolinguistics in EFL classroom students are trained to raise their sense on ecological awareness. They are taught to love and appreciate their environment and preserve the natural and cultural heritage they already have in a simple way. By giving them various ecolinguisticsbased learning materials, students are expected to have broad minded and consideration on each other's social reality and necessarily students can enhance their responsibility and introspection to ecological 
crisis (such as smoke problem in Central Kalimantan) they find in their surroundings.

\section{THE DEVELOPMENT OF ECOLINGUISTIC- BASED LESSON PLAN}

One of teacher's responsibilities before conducting teaching learning activities in the classroom is making lesson plans. There are several steps to be done in making a lesson plan. The first step is formulating the learning objectives or the teaching goal. The next step is selecting content. After that is developing teaching learning process by using student-centered activities involving media and material designed to help students achieve the learning objectives. The last step is making the assessment.

The following discussion gives the examples of developing ecolinguistic-based lesson plan. Ecolinguistics-based lesson plan is a design to prepare what the teachers want to do in the classroom by inserting learning materials with ecolinguistics content.The first step in planning ecolinguistics-based lesson plan is formulating the learning objective or teaching goal. According to Mukminatien (2014), “A goal is an overall target of achievement in a lesson that is broken down into specified instructional objectives. The specified instructional objectives are stated using action verbs showing desired student behavior, which is observable and measurable." The goal is suited with the competency standards on each skill to be taught to the students. According to Kemendiknas (2006), the competency standard for listening skill is to understand instructions, information and simple stories which are presented verbally in class, school, and community context; for speaking skill is to express verbal meanings in interpersonal and transactional discourses in the form of instructions and information in class, school, and community context; for reading skill is to read aloud and understand the meaning of instructions, information, short functional texts and descriptive texts which are presented in written forms in class, school, and community context; and for writing skill is to write words, expressions and short functional texts with correct spelling and punctuation.

The next step is selecting the content. In doing this step, teachers should use ecolinguistics content to be inserted in the lesson plan. There are various forms of ecolinguictics content that can be used by the teachers. Some of them have been available in written forms and can be accessed through internet, social media, printed books, etc; but teachers can also create their own ecolinguistics content based on the real belief, oral culture or literature, local wisdom, people ways of life, etc that have been handed down from one generation to next generation in the region. The ecolinguistics contents then are realized in the forms of learning materials to be used in the classroom. After that teachers develop the steps in teaching learning process. Mainly the teaching learning process is organized in three-phase technique; they are the pre-learning, the implementation stage consisting of the main teaching learning activities, and the post-learning stage. To support the success in this step, certain approach (such as CTL/Constructivist/SA approach), methods (such as Project-Based Learning, Genre-Based Learning or Problem-Based Learning), and teaching technique (such as discussion, reconstruction, representation, etc), as well as various sources and media as the teaching aids can be applied in implementing ecolinguistics-based lesson plan.

The last step is giving the assessment to students to measure their understanding and comprehension on the lesson taught. The forms of the assessment and the assessment rubric are suited with each language skill to be assessed. Teachers may also make some assessment focusing on the ecolinguistics point of view by giving exercises for students to comprehend meanings of a lexicon list of environmental expressions taken from the texts.

Actually all the steps in making ecolinguisticsbased lesson plan previously discussed have been introduced and socialized to the English teachers in several junior high schools in Kuala Kapuas, Central Kalimantan in 2016. It was done in three stages; the pre stage, main stage, and post stage. In pre stage, teachers were given some topics on transanctional and interpersonal of narrating past events and home life, then they were asked to make lesson plans on those topics on their own version. Most teachers took and used the teaching materials on those topics from the textbooks they commonly used for teaching English (The textbook and workbook of "Way Point Plus" by Giuliano Iantorno \& Mario Papa, published by Erlangga, 2007). Some of the materials were in the forms of recorded dialogues and scripts of making something, some explanation on the grammar used to support the topics, and relevant pictures. The focus of the teaching learning was mostly on listening skill as teachers played the recording and asked students to pay attention to it. To assess students' understanding on the topics, some questions (True/False) and rewriting of the topics being discussed should be done by the students. It can be said that all the exercises done by students have been available in the textbook and workbook used at those schools.

In the main stage, teachers were guided and supervised to make their lesson plans on the same topics given in the pre stage by inserting ecolinguistics content. Teachers may use the materials having ecolinguistics content prepared by the researchers or they may create their own ecolinguistics-based materials. There were several adjustments made to suits the goal of teaching English using ecolinguistics-based lesson plans, particularly on the skill being the focus of the teaching and the methods of teaching learning. For 
having the clear description of ecolinguistics-based lesson plan made by the teachers, there are two examples of lesson plans having ecolinguistics content discussed in this sub-section.The first example of the ecolinguistics-based lesson plan was made by a teacher in SMPN 3 SELAT, Kuala Kapuas based on School-Based Curriculum using a narrative text of a local story entitled "Fish without Scales" as the learning material for eight graders. This narrative was prepared by the researchers and was written based on the oral story exists in Henda district, a small district along the Kahayan River side in the southern of Palangka Raya City. The text can be seen in Excerpt 1:

\section{Excerpt 1:}

Fish without Scales

This story was happened in Henda District, a small district along the Kahayan River side in the southern of Palangka Raya City.

Once upon a time, a colony of worms attacked the district. The first time, they attacked plants. The plants ran out. Then the worms began attacking the animals, such as chickens and pigs. After that, the worms began to attack human beings. In this situation, a man climbed up a tree which grew up at the side of a river. The tree was bended down right to the water of the river. Suddenly, this man heard a voice from under the water. It said, "Jump to the water. I guarantee that the worms cannot reach you." The man looked at the people who were attacked by the worms. Finally, he jumped into the river. The worms still followed the man to the river. When the worms reached the water, all the fish without scales, such as catfish, lais, and baung fish, came and eat the worms. All the people followed the man jumping to the river and the worms went back to the land. Then, the fish said to the people, "Do not go far from the river and live here. If the worms come back, I promise to help you. But, what can you do for me?" Then, the people decided to live near the river. They also promised not to eat the fish without scales.

The goal of teaching English using this narrative text is to build up students' writing skill. For the indicators to be achieved, students should be able to identify the information carried in the text by giving correct answers to the questions given after the text was read orally by the teacher using the method of Total Physical Respond for Story Telling. In the main stage of teaching learning activities, the text was read more than once and students were asked to pay attention to the nouns and prominent vocabularies found in the text. To test students' understanding and comprehension to the text, there were two students asked to retell it in Bahasa Indonesia. After that students were given the questions to answer related to the content of the text. The last activity was asking students to rewrite a short and simple narrative text using correct generic structures based on their answers to the questions which followed the narrative text. A scoring rubric for writing was used to assess students' works in rewriting of the narrative text.
The second example of ecolinguistics-based lesson plan uses a procedure text of how to make traditional soup from young rattan. This lesson plan was made by the English teacher of SMP Negeri 1 Selat, Kuala Kapuas based on Curriculum 2013 using a shopping list of the ingredients needed to cook the young rattan soup, a procedure text of how to cook the soup, relevant pictures of the real objects used when the lesson plan was executed in the classroom. In the execution stage, real objects of the ingredients and tools used to cook the soup were used as the media and tools of learning. The ecolinguistics-based lesson plan of cooking traditional soup from young rattan can be seen in the following lesson plan.

\section{Lesson Plan}

School

Subject

Grade/Semester

Topic

making

Skills

Time Allocation : $2 \times 40$ minutes

\section{A. Core Competencies}

1.3 Understanding, applying, analyzing factual, conceptual, procedural knowledge based on curiosity about science, technology, art, culture, and humanities with humanitarian insight, nationality, state and civilization on the causes of phenomenon and events, and applying procedural knowledge to specific areas of study in accordance with their talents and interests to solve problems.

1.4 Processing, reasoning, and chanting in the realm of concrete and abstract spheres linked to the development of the self-studied school, and capable of using methods according to scientific rules

\section{B. Basic Competencies}

1.3 Applying text structures and linguistic features to fulfill the social function of procedure text in the form of shopping list for asking and stating about recipes and manuals, the activities and events, short and simple according to the context of its use.

1.4 Arranging procedure text, oral and written, short and simple, recipes and manually shaped, according to the proper and correct social function, text structure and linguistic features.

\section{Learning Objectives}

In the end of the lesson, students are able to:

1.1 Appreciate the opportunity to learn English as an international language consistently.

1.2 Show the honest, discipline, confident, and responsibility behaviors in everyday life.

1.3 Explain the text structure and linguistic features of procedure text correctly, to carry out the procedure text according 
to its social function of the text for asking and stating about recipes and manuals, short and simple, according to the context of its use.

1.4 Make and present procedure text orally and in written form, short and simple, recipes and manually shaped, according to the proper and correct social function, text structure and linguistic features.

\section{Learning Materials}

1. A shopping list of the ingredients and tools needed for cooking the traditional soup from young rattan

2. A procedure text of making traditional soup from young rattan accessed from http://carabuatresep.blogspot.co.id/2015/10/c ara-membuat-sayur-umbut- rotan.html

3. Pictures of real objects (ingredients) for cooking the traditional soup from young rattan

4. Definition of Procedure Text:

Procedure text is a text which gives instructions on how to do or how to make something

5. Social Function: To describe how something is done or accomplished through a sequence of action/steps.

The Text Structures

a. Goal/Aim/Title : Introducing the traditional cuisine of JuhuSingkah (Young Rattan Soup)

b. Ingredients/Materials : Listing all ingredients needed to cook JuhuSingkah (Young Rattan Soup).

c. Series of steps/actions : Describing the procedures of cooking JuhuSingkah (Young Rattan Soup).

The Language Features of Text

(1) Using of Imperative as Simple Present Tense form: e.g. cut, wash, boil, etc .

(2) Using of Action Verbs: e.g. turn, put, mix, shake, etc.

(3) Using of Temporal Conjunctions: e.g. first, then, after that, before, at last, finally, etc.

(4) Using of Adverbs: e.g. slowly, carefully, lightly, etc.

(5) Introducing Vocabularies of all ingredients: e.g.

(6) The correct use of singular dan plural nouns in Noun Phrases, with or without $a$, the, this, those, my, their, etc.

(7) Speech, words stress, intonation, when presented orally.

\section{E. Teaching Methods}

1. Approach: Scientific Approach

2. Method : Audio-Lingual Method

\section{F. Media, Source and Tools}

1. Media
worksheet

2. Tools/Ingredients : all ingredients and tools needed to cook 'rattan soup'
3. Source : adapted from
http://carabuatresep.blogspot.co.id/2015/10/ca ra-membuat-sayur-umbut-rotan.html

\section{G. Learning Activities}

Table 1. Learning Activities

\begin{tabular}{lll}
\hline Activity & \multicolumn{1}{c}{ Learning Activities } & $\begin{array}{l}\text { Time } \\
\text { Allocation }\end{array}$ \\
\hline Pre & 1. & $\begin{array}{l}\text { Greeting and saying the prayer to } \\
\text { start the lesson }\end{array}$ \\
& 2. & $\begin{array}{l}\text { Stating the learning objectives of } \\
\text { the lesson }\end{array}$ \\
& 3. & $\begin{array}{l}\text { Giving information of the topic, } \\
\text { learning objectives, and activities } \\
\text { to be done }\end{array}$ \\
& 4. $\begin{array}{l}\text { Brainstorming: } \\
\text { "Have you ever helped your } \\
\text { mother cooking?" }\end{array}$ \\
& "What is your favorite food?" \\
\hline
\end{tabular}

$\begin{array}{ll}\text { Main } & \text { Observing } \\ \text { Activities } & \bullet \text { Asking students to observe the }\end{array}$ 45 ingredients for cooking Juhu Singkah "Young Rattan Soup".

- Paying attention to teacher's explanation on the ingredients and tools needed for cooking Juhu Singkah "Young Rattan Soup".

- Watching and taking notes on the ingredients and steps for cooking Juhu Singkah "Young Rattan Soup".

\section{Questioning}

- Giving chances to students to ask questions about the ingredients and steps to cook Juhu Singkah "Young Rattan Soup".

- Leading students by asking them to identify the text structure, linguistic features, and social function of procedure text of making Juhu Singkah "Young Rattan Soup".

Exploring

- Dividing students into several groups consisting of 4-5 members

- Asking them to make the list of ingredients (at least 10 nouns) needed to cook Juhu Singkah "Young Rattan Soup"

- Asking the group to present the result of the list they make in front of the class orally (Oral Test).

- Asking the group to retell the steps in cooking Juhu Singkah "Young Rattan Soup" (Oral Test)

\section{Associating}

- Asking students to identify the social function, text structures and linguistic features of the procedure text of cooking Juhu Singkah "Young Rattan Soup".

- Giving feedbacks to students on 
the materials learned and relating it to similar type of procedure text on recipes/manuals.

\section{Communicating}

- Asking students to write a brief description on each ingredient mentioned on the shopping list used for cooking Juhu Singkah "Young Rattan Soup" (Written Test)

- Asking them to rerite the procedure text of cooking Juhu Singkah "Young Rattan Soup" using the correct text structures and linguistic features (Written Test).

$\begin{array}{ll}\text { Post } & \text { 1. Giving oral questionnaire as the } \\ \text { Activity } & \text { feedback in learning procedure text } \\ \text { based on ecolinguistics } & \text { perspective. } \\ \text { 2. Drawing conclusion on the topic } \\ \text { has been learned } \\ \text { 3. Giving assignment to students } \\ \text { related to ecolinguistics } \\ \text { materials. }\end{array}$

a. Learning Activities

\section{H. ASSESSMENT}

1. Types of assessment: Oral Test and Writing Test

2. Scoring Rubric.

Table 2. The Scoring Rubric of Speaking

\begin{tabular}{|c|c|c|c|}
\hline $\begin{array}{c}\text { Speaking } \\
\text { Aspects }\end{array}$ & Weight & Score & Level \\
\hline Pronunciation & \multirow[b]{2}{*}{10} & $\begin{array}{c}90-100 \\
81-90\end{array}$ & $\begin{array}{c}\text { Excellent } \\
\text { Very Good }\end{array}$ \\
\hline Fluency & & $\begin{array}{c}76-80 \\
65-75 \\
0-64\end{array}$ & $\begin{array}{l}\text { Good } \\
\text { Fair } \\
\text { Poor }\end{array}$ \\
\hline$\overline{\mathrm{ng} \mathrm{sco}}$ & & $\frac{)+(\mathrm{B} \times \text { rig }}{2}$ & wer) X 100\% \\
\hline
\end{tabular}

Table 3. The Scoring Rubric of Writing (Cloze Test)

\begin{tabular}{|c|c|c|c|}
\hline $\begin{array}{c}\text { Speaking } \\
\text { Aspects }\end{array}$ & Weight & Score & Level \\
\hline Vocabulary & \multirow[b]{2}{*}{10} & \multirow{2}{*}{$\begin{array}{c}90-100 \\
81-90 \\
76-80 \\
65-75 \\
0-64\end{array}$} & \multirow{2}{*}{$\begin{array}{c}\text { Excellent } \\
\text { Very Good } \\
\text { Good } \\
\text { Fair } \\
\text { Poor }\end{array}$} \\
\hline Spelling & & & \\
\hline Writing score: & ght answ & $\frac{+(\mathrm{B} \times \text { righ }}{2}$ & swer) X 100\% \\
\hline
\end{tabular}

This lesson plan was used for training students in their writing and speaking skills. Scientific Approach and Audio Lingual Method were applied in the execution of this lesson plan. Moreover real objects and tools needed for cooking demonstration were also used, and to test students' understanding and comprehension, they were asked to make the list of the ingredients and mentioned them orally in front of the class with correct pronunciation and spelling. They were also asked to write a brief description on each ingredient needed to cook Juhu Singkah for example by mentioning the common place they usually find that ingredient or describing the taste, characteristics or benefit that ingredient has. They did this task in small group. After that they were asked to rewrite the procedure text of making Juhu Singkah using the correct text structures and linguistic features. The results of their oral and written performances were scored using the scoring rubric for speaking and for writing.

The last stage in introducing ecolinguistic-based lesson plan was the post stage. In this stage, teachers executed the ecolinguistics-based lesson plans they already made into the real teaching learning activities in their classrooms. Students' response and participation to the process of teaching learning using ecolinguistic-based lesson plans were observed, and their worksheets were scored using the suitable scoring rubric for the skill being emphasized in the teaching learning process. The results showed that (1) the students were very more motivated and enthusiastic, especially when the students talked about the linguistic expressions they know well ecolinguistics of animals and plants or ingredients, (2) the students' tasks could show a meaningful learning as well as promoting local area by using linguistic expressions or familiar vocabulary lists, (3) the students' mean scores achieved the school passing grade of 65 although there were some mistakes in language features (Luardini and Simbolon, 2016). The implementation of ecolinguistics-based lesson plan in several junior high schools in Kuala Kapuas can be used as the ecolinguistics-based teaching model for other junior high schools particularly in other regions of Central Kalimantan.

\section{CONCLUSION}

Ecolinguistics can be used as one alternative in answering the gap between the curriculum demand on the local content development and the lack of local content development on the provided materials being used to teach English in Central Kalimantan. The teaching model by using ecolinguistics-based lesson plans has been conducted in two junior high schools in SMPN 1 and SMPN 3, Kuala Kapuas. The use of ecolinguistics-based lesson plans bring two positive values on students' motivation and comprehension in learning English,as well as they become more aware on their own culture and environment where they belong to. Teachers should be more creative in preparing and creating their lesson plans using ecolinguistics perspectives. They may relate the phenomena found in their surroundings to become the ecolinguistic-based materials used for teaching English in their classroom. By understanding ecolinguistics - the use of environmental linguistic expressions, it will lead to a meaningful teaching and learning process. Therefore, as the follow-up it is 
necessary to develop instructional material consisting of environmental linguistic expressions.

\section{REFERENCES}

[1] G. Eason, B. Noble, and I. N. Sneddon, "On certain integrals of Lipschitz-Hankel type involving products of Bessel functions," Phil. Trans. Roy. Soc. London, vol. A247, pp. 529-551, April 1955. (references) Dharma A. (2008). Indonesian Basic Education Curriculum Current Content And Reform. Presented in Round table Discussion in Retrac Governing Board Meeting at Institute AminuddinBaki, Genting Highland, Malaysia. Retrieved from http://www.ibe.unesco.org/curricula/indonesia/io_befw_2008 _eng.pdf

[2] Haugen, E. (1972). The Ecology of Language. Standfort: University Press.

[3] Kana' 'iaupuni, S., Brandon L., 'Umi Jensen. (2010). CultureBased Education and Its Relationship to Student Outcomes. Retrieved from http://www.ksbe.edu/_assets/spi/pdfs/CBE_relationship_to_st udent_outcomes.pdf

[4] Luardini, M. A. and Simbolon, M. (2016). Ecolinguistics for Teaching English. The Asian EFL Journal: Professional Teaching Articles, Indonesian International Conference Vol. 3. 238-248.

[5] Morris, Edward K; Nathaniel G.S.; and Deborah E.A. B. F (2005). Skinner's contributions to applied behavior analysis. Behav. Anal. 2005; 28(2), p. 99 - 131. Retrieved from http://www.ncbi.nlm. nih.gov/pmc/articles /PMC2755377/

[6] Mukminatien, Nur. (2014). Implementing Genre-Based Approach to Develop a Worksheet for Teaching Writing in a Book of Material and Media in English Language Teaching. Edited by B.Y. Cahyono and F. Megawati. Chapt.11, page 153-164. State Uni. Of Malang Press.

[7] Nur, Maulidia Rachmawati and Madkur, Ahmad. (2014) Teachers' Voices on the 2013 Curriculum for English Instructional Activities. IJEE, Vol. 1, No.2, p. 119-133.

[8] Singh, N.K and Espinoza-Herold, M. (2014). Culture-Based Education: Lessons from Indigenous Education in the US and Southeast Asia. Nabe Journal of Research and Practice. Vol. 52014 , page $1-33$.

[9] The Ministry of National Education and Culture. (2013). Buku Untuk Guru Kelas VII 'Handouts for the Teacher of VII Graders'. Jakarta: The Ministry of National Education and Culture.

[10] The Ministry of National Education and Culture. (2003). Undang-Undang Sistem Pendidikan Nasional National Education System Constitution'. Jakarta: The Ministry of National Education and Culture.

[11] Tjendani, EN. (2017). Ecolinguistics Approach for English Learning Activities at Junior High School. The International Journal of Social Science and Humanities Invention. ISSN: 2349-2031. Vol. 4 No. 8.

[12] Wendel, J., (2005). Notes on the Ecology of Language. In: Bunkyo Gakuin University Academic Journal 5, 511-516. 